LINGUA, Vol. 12, No. 1, Maret 2015

p ISSN: 1979 9411; e ISSN: 2442 238X; Web: lingua.pusatbahasa.or.id Pusat Kajian Bahasa dan Budaya, Surakarta, Indonesia

Suhartono, J. Parmin \& Wibowo, AN, Yermia. 2015. Pengembangan Modul Membaca dan Menulis Berbasis Uji Diagnostik untuk Meningkatkan Pemahaman Siswa SMP terhadap Materi Pokok Bahasa Indonesia. Lingua, 12(1): 23 38.

\title{
PENGEMBANGAN MODUL MEMBACA DAN MENULIS BERBASIS UJI DIAGNOSTIK UNTUK MENINGKATKAN PEMAHAMAN SISWA SMP TERHADAP MATERI POKOK BAHASA INDONESIA ${ }^{1}$
}

\author{
${ }^{2}$ Suhartono, J. Parmin, dan Yermia Nugroho Agung Wibowo \\ Universitas Negeri Surabaya \\ Email: hartobosuhartono@yahoo.co.id
}

\begin{abstract}
The objective of this study is to devise a Diagnostic-Test-Based of Reading and Writing Module of Bahasa Indonesia for SMP students. The study fcuses on the instructional design of the core materials of Bahasa Indonesia in the School-Based Curriculum. The study uses Research and Development design implementing three circles of activity: planning, designing and development. Research subjects included 27 ninth gragers of SMPN 28 Surabaya. The study reveals that in the planning stage, core materials of reading and writing were selected by the schools and be listed as Table of Specification before National Leaving Exam. Analysis of diagnostic test indicated that core materials of reading and writing for Bahasa Indonesia deviated problems students faced so that students received no benefits. The development of the module empirically proved that Diagnostic Test-Based Reading and Writing module increased students accomplishment up to $23.03 \%$.
\end{abstract}

Key-words: module, reading and writing, diagnostic test.

Keterampilan berbahasa terdiri atas 4 jenis: menyimak, berbicara, membaca, dan menulis. Menyimak dan berbicara merupakan keterampilan lisan: menyimak reseptif, berbicara produktif. Membaca dan menulis merupakan keterampilan tulis: membaca reseptif, menulis produktif. Perbedaan dan persamaannya divisualkan pada tabel 1.

Tabel 1. Keterampilan Berbahasa

\begin{tabular}{|c|l|l|}
\hline & \multicolumn{1}{|c|}{ Reseptif } & \multicolumn{1}{c|}{ Produktif } \\
\hline Lisan & Menyimak & Berbicara \\
\hline Tulis & Membaca & Menulis \\
\hline
\end{tabular}

Dalam pembelajaran Bahasa Indonesia (BI) di SMP, proporsi keempat keterampilan itu seimbang, sebagaimana tampak pada distribusi standar kompetensi (SK) dan kompetensi dasar (KD) berikut.

\footnotetext{
${ }^{1}$ Artikel ini ialah bagian dari Hasil Penelitian Hibah Bersaing 2014

${ }^{2}$ Dosen dosen Jurusan Bahasa dan Sastra Indonesia FBS Unesa
} 
LINGUA, Vol. 12, No. 1, Maret 2015

p ISSN: 1979 9411; e ISSN: 2442 238X; Web: lingua.pusatbahasa.or.id Pusat Kajian Bahasa dan Budaya, Surakarta, Indonesia

Suhartono, J. Parmin \& Wibowo, AN, Yermia. 2015. Pengembangan Modul Membaca dan Menulis Berbasis Uji Diagnostik untuk Meningkatkan Pemahaman Siswa SMP terhadap Materi Pokok Bahasa Indonesia. Lingua, 12(1): 23 38.

Tabel 2 Distribusi SK dan KD Mapel BI SMP

\begin{tabular}{|l|c|c|c|}
\hline \multirow{2}{*}{$\begin{array}{c}\text { Keterampilan } \\
\text { Berbahasa }\end{array}$} & \multicolumn{3}{|c|}{ SMP } \\
\cline { 2 - 4 } & Kelas & SK & KD \\
\hline Menyimak & VII & 4 & 8 \\
\hline Berbicara & VII & 4 & 8 \\
\hline Membaca & VII & 4 & 10 \\
\hline Menulis & VII & 4 & 9 \\
\hline Menyimak & VIII & 4 & 9 \\
\hline Berbicara & VIII & 4 & 8 \\
\hline Membaca & VIII & 4 & 10 \\
\hline Menulis & VIII & 4 & 10 \\
\hline Menyimak & IX & 4 & 8 \\
\hline Berbicara & IX & 4 & 8 \\
\hline Membaca & IX & 4 & 9 \\
\hline Menulis & IX & 4 & 10 \\
\hline
\end{tabular}

(Diolah dari Depdiknas, 2006)

Keseimbangan itu tidak tampak pada kegiatan evaluasi, khususnya ujian nasional (UN). Hal itu dapat diamati pada distribusi KD, sebagaimana yang tampak pada tabel 3.

Tabel 3 Distribusi KD dalam UN BI SMP 2012/2013

\begin{tabular}{|c|c|}
\hline $\begin{array}{c}\text { Keterampilan } \\
\text { Berbahasa }\end{array}$ & Jumlah KD \\
\hline Menyimak & 0 \\
\hline Berbicara & 0 \\
\hline Membaca & 11 \\
\hline Menulis & 15 \\
\hline
\end{tabular}

(Diolah dari Depdikbud, 2012)

Distribusi KD yang tidak proporsional itu, di samping tidak semua KD pada keterampilan membaca dan menulis di-UN-kan, menunjukkan KD yang di-UN-kan merupakan materi terpilih (materi pokok). Seperti yang contohnya tersaji pada tabel 4, tingkat kesulitan materi pokok itu berbeda.

Sejauh ini penyusunan materi pokok keterampilan membaca dan menulis telah dilakukan, tetapi tidak komprehensif dan tidak memertimbangkan tingkat kesulitan sehingga tidak ada tambahan penjelasan dan contoh pada materi yang bertingkat kesulitan tinggi. Dengan kata lain, belum ada pengembangan materi pokok yang berkonsentrasi pada materi sulit.

Di samping itu, pengembangan materi pokok sejauh ini tidak berbasis uji diagnostik sehingga tidak menjadi solusi terhadap kesulitan siswa. Siapa yang bertanggung jawab untuk mendiagnosis juga tidak jelas. Kenyataan bahwa pemerintah sebagai penyelenggara pendidikan dan penanggung jawab UN tidak memberikan hasil mentah UN kepada pihak sekolah merupakan akar masalah yang menyebabkan soal-soal sulit tidak terdeteksi. 
LINGUA, Vol. 12, No. 1, Maret 2015

p ISSN: 1979 9411; e ISSN: 2442 238X; Web: lingua.pusatbahasa.or.id

Pusat Kajian Bahasa dan Budaya, Surakarta, Indonesia

Suhartono, J. Parmin \& Wibowo, AN, Yermia. 2015. Pengembangan Modul Membaca dan Menulis Berbasis

Uji Diagnostik untuk Meningkatkan Pemahaman Siswa SMP terhadap Materi Pokok Bahasa Indonesia. Lingua, 12(1): 23 38.

Akibatnya, washback UN tidak dapat digunakan untuk meningkatkan kinerja akademik sekolah dan pihak lain yang berkepentingan. Karena itu, uji diagnostik secara independen melalui penelitian ini berperan strategis sebagai basis pengembangan materi pokok untuk meningkatkan pemahaman siswa.

Tabel 4 Tingkat Kesulitan KD BI UN SMP 2012/2013 Beberapa Sekolah di Surabaya

\begin{tabular}{|c|c|c|c|c|c|}
\hline \multirow[t]{2}{*}{ SMP } & \multicolumn{5}{|c|}{ Capaian (dalam \%) } \\
\hline & KD & Sekolah & Kota Surabaya & Provinsi Jatim & Nasional \\
\hline SMPN 1 & Menulis teks pidato & 85,36 & 64,44 & 64,65 & 59,07 \\
\hline & Melengkapi pantun & 98,21 & 90,21 & 89,40 & 84,50 \\
\hline SMPN 2 & Menulis teks pidato & 78,99 & 64,44 & 64,65 & 59,07 \\
\hline \multirow{3}{*}{ SMPN 3} & Melengkapi pantun & 94,38 & 90,21 & 89,40 & 84,50 \\
\hline & Menulis teks pidato & 72,45 & 64,44 & 64,65 & 59,07 \\
\hline & Melengkapi pantun & 96,98 & 90,21 & 89,40 & 84,50 \\
\hline
\end{tabular}

Hal menarik lainnya adalah materi pokok yang dikembangkan selama ini tidak berformat modul. Akibatnya siswa kesulitan merencanakan, melaksanakan, dan mengevaluasi kinerja belajarnya secara mandiri. Dengan "belajar" dari kelemahan-kelemahan itu, melalui penelitian ini dikaji dua hal: (1) proses perencanaan, perancangan, dan pengembangan modul membaca dan menulis berbasis uji diagnostik untuk meningkatkan pemahaman siswa SMP terhadap materi pokok BI dan (2) pemahaman siswa SMP terhadap materi pokok BI sebelum dan setelah menggunakan modul.

Materi pembelajaran mengacu materi-materi yang disiapkan sebaik-baiknya dan ditulis secara khusus untuk mencapai tujuan pembelajaran. Materi pembelajaran berisi materi untuk tujuan-tujuan pokok dan materi remidi atau pengayaan (Dick dan Carey, 1990:205-206).

Richards (2003:252 - 253) membagi materi pembelajaran ke dalam dua kategori: autentik (authentic materials) dan buatan (created materials). Materi autentik adalah materi pembelajaran yang tidak disiapkan secara khusus untuk tujuan pedagogis, sedangkan materi buatan adalah materi pembelajaran yang dikembangkan dari sumber-sumber pembelajaran. Materi autentik lebih baik daripada materi buatan karena 1) berefek positif dalam memotivasi pebelajar karena secara intrinsik lebih menarik dan motivatif, 2) menyediakan informasi kultural autentik tentang budaya sasaran (target culture), 3) menyediakan pajanan (exposure) bahasa nyata, 4) menghubungkan lebih dekat dengan kebutuhan pebelajar, dan 5) mendukung pendekatan pengajaran yang lebih kreatif. Ahli lain yang berpendapat berbeda menyatakan bahwa terlepas dari kelemahannya, materi buatan juga memiliki kelebihan karena 1) juga dapat memotivasi pebelajar, 2) bahasanya sudah disederhanakan sesuai dengan kebutuhan pebelajar, 3) berbasis silabus, dan 4) tidak memberatkan guru.

Materi pembelajaran idealnya diseleksi dan dipastikan memadai untuk melayani kebutuhan akademik. Di samping itu, sejalan dengan yang dinyatakan Dick dan Carey (1990:205-206), juga diperlukan evaluasi untuk menentukan apakah 1) memerhatikan kepedulian motivasional siswa, 2) mencakup butir-butir materi yang cocok, 3) sekuensinya benar, 4) semua butir materi yang diperlukan dapat digunakan,5) terdapat praktik perlatihan, 
LINGUA, Vol. 12, No. 1, Maret 2015

p ISSN: 1979 9411; e ISSN: 2442 238X; Web: lingua.pusatbahasa.or.id

Pusat Kajian Bahasa dan Budaya, Surakarta, Indonesia

Suhartono, J. Parmin \& Wibowo, AN, Yermia. 2015. Pengembangan Modul Membaca dan Menulis Berbasis

Uji Diagnostik untuk Meningkatkan Pemahaman Siswa SMP terhadap Materi Pokok Bahasa Indonesia. Lingua, 12(1): 23 38.

6) mencakup balikan yang memadai, 7) tes yang cocok dapat digunakan, 8) perintah tindak lanjut yang memadai mencakup untuk remediasi, kerja tingkat lanjut, atau kerja umum, dan 9) panduan pebelajar yang memadai disediakan untuk mengubah siswa dari aktivitas tertentu ke aktivitas berikutnya.

Materi pembelajaran berciri 1) membuat siswa tertarik, 2) mengingatkan siswa pada pembelajaran sebelumnya, 3) memberi tahu siswa tentang apa yang akan dipelajarinya, 4) menjelaskan isi materi pembelajaran yang baru, 5) menghubungkan ide-ide dengan apa yang sebelumnya dipelajari siswa, 6) mengondisikan siswa untuk berpikir tentang isi materi yang baru, 7) membantu siswa mendapatkan balikan pembelajaran, 8) mendorong siswa untuk berlatih, 9) meyakinkan siswa untuk mengetahui apa yang seharusnya dilakukan, 10) membuat siswa dapat mengecek kemajuan belajar, dan 11) membantu siswa melakukan yang lebih baik (Rowntree dalam Richards, 2003:263). Pendapat senada dikemukakan oleh Tomlinson (Richards, 2003:263) bahwa materi yang baik berciri 1) berpengaruh, 2) membantu pebelajar merasa mudah, 3) membantu pebelajar mengembangkan kepercayadirian, 4) relevan dan berguna, 5) menghendaki dan memfasilitasi pebelajar melakukan investasi diri, 6) mengantisipasi perbedaan gaya belajar dan sikap siswa, 7) memaksimalkan potensi pembelajaran dengan mendorong aspek intelektual, aestetik, dan emosional yang menstimulasi aktivitas otak kiri dan kanan siswa, 8) tidak terlalu mengontrol siswa, dan 9) menyediakan peluang akan balikan hasil.

Pendapat lain dikemukakan oleh Dubin dan Olshtain (1986:29) bahwa dalam materi pembelajaran idealnya dipertimbangkan 1) kesesuaian isinya dengan silabus, 2) ketersediaan alternative bagi guru dan siswa, 3) keautentikan tipe teks yang digunakan, dan 4) hubungannya dengan faktor eksternal, misalnya sosiokultural.

Pengembangan materi pembelajaran memiliki tiga landasan: ilmu bahasa dan sastra, ilmu pendidikan dan keguruan, dan keterbacaan materi dan bahasa yang digunakan (Depdiknas, 2005:6-12). Landasan keilmuan berorientasi pemastian lingkup keilmuan mata pelajaran. Dengan pemastian itu dapat diketahui struktur keilmuan yang berguna dalam menentukan cakupan dan susunan materi.

Landasan ilmu pendidikan dan keguruan berorientasi pemastian kaidah pendidikan dan keguruan. Dengan pemastian itu dapat diketahui karakteristik siswa dan metode serta teknik penyampaian materi dalam pemilihan bahan dan penentuan luas cakupan materi serta urutannya.

Landasan keterbacaan materi dan bahasa berorientasi pemastian cara pengolahan materi sehingga siswa mudah memahaminya. Termasuk dalam hal itu pengaturan panjang dan susunan kalimat dan pemilihan kosakata yang mudah dipahami.

Shulman (Richards, 2003:262) menyatakan terdapat empat fase pengembangan materi pembelajaran: 1) preparasi, 2) representasi, 3) seleksi, dan 4) adaptasi dan pengenalan karakteristik siswa. Preparasi mencakup interpretasi dan analisis kritis terhadap teks, penstrukturan dan segmentasi, pengembangan sajian kurikular, dan klasifikasi tujuan. Representasi mencakup penggunaan sajian representasional yang meliputi analogi, metafora, contoh, demonstrasi, eksplanasi, dan sejenisnya. Seleksi mencakup pilihan terhadap sajian instruksional yang meliputi cara mengajarkan, mengorganisasi, mengelola, dan menyusun 
LINGUA, Vol. 12, No. 1, Maret 2015

p ISSN: 1979 9411; e ISSN: 2442 238X; Web: lingua.pusatbahasa.or.id

Pusat Kajian Bahasa dan Budaya, Surakarta, Indonesia

Suhartono, J. Parmin \& Wibowo, AN, Yermia. 2015. Pengembangan Modul Membaca dan Menulis Berbasis

Uji Diagnostik untuk Meningkatkan Pemahaman Siswa SMP terhadap Materi Pokok Bahasa Indonesia. Lingua, 12(1): 23 38.

materi. Adaptasi dan pengenalan siswa mencakup pertimbangan konsepsi, prakonsepsi, miskonsepsi, dan kesulitan; bahasa, budaya, dan motivasi; dan kelas sosial, gender, usia, kemampuan, bakat, ketertarikan, konsep diri, dan perhatian.

Empat fase itu mendasari draf I materi pembelajaran. Menurut Richards (2003:268), draf I idealnya mendapatkan komentar sebagai dasar draf II. Draf II mendapatkan komentar lanjutan sebagar dasar uji coba materi. Materi yang sudah diujicobakan selanjutnya direvisi. Prosedur tersebut tidak baku. Adaptasi dapat dilakukan dengan menambahkan kegiatan yang diperlukan, misalnya pengembang materi pada tahap pertama dapat merencanakan pendekatan sistem (Puskur, 2005:1) atau menelaah kurikulum (Depdiknas, 2005:13).

Kualitas materi pembelajaran juga dapat diketahui dengan menggunakan indikator yang operasional. Pusat Perbukuan (2007), sebagai contoh, menggunakan empat indikator penilaian kualitas buku, yaitu kelayakan isi, penyajian, bahasa, dan kegrafikaan. Keempat indikator itu dalam instrumen penilaian berskala $1-5$ dinilai dengan berbasis komponen dan butir penilaian berikut

1. Kelayakan isi: a) kesesuaian uraian materi dengan Sk dan KD (butir penilaian: kelengkapan materi dan kedalaman materi); b) keakuratan materi (butir penilaian: keakuratan dalam pemilihan wacana, keakuratan dalam konsep dan teori, keakuratan dalam pemilihan contoh, dan keakuratan dalam pelatihan); dan c) materi pendukung pembelajaran (butir penilaian: kesesuaian dengan perkembangan ilmu; kesesuaian fitur, contoh, dan rujukan; pengembangan wawasan kebinekaan; dan pengembangan wawasan kebangsaan dan integrasi bangsa)

2. Kelayakan penyajian: a) teknik penyajian (butir penilaian: konsistensi sistematika penyajian, keruntutan konsep, dan keseimbangan antarbab); b) penyajian pembelajaran (butir penilaian: keterpusatan pada peserta didik, merangsang metakognisi peserta didik, dan merangsang daya imajinasi dan kreasi berpikir peserta didik); dan c) kelengkapan penyajian (butir penilaian: bagian pendahulu, bagian isi, dan bagian penyudah)

3. Kelayakan bahasa: a) kesesuaian dengan perkembangan peserta didik (butir penilaian: Kesesuaian dengan perkembangan intelektual, Kesesuaian dengan perkembangan sosial emosional; b) komunikatif (butir penilaian: kesesuaian dengan tingkat keterbacaan bahasa dan ketepatan bahasa); dan c) keruntutan dan kesatuan gagasan (butir penilaian: keruntutan dan keterpaduan bab serta keruntutan dan keterpaduan paragraf)

4. Kelayakan kegrafikaan: a)ukuran buku (butir penilaian: kesesuaian ukuran buku dengan standar ISO dan kesesuaian ukuran dengan materi isi buku); b) desain kulit buku (butir penilaian: penampilan unsur tata letak pada kulit muka, belakang, dan punggung harmonis dan konsisten; penampilan pusat pandang (center point) baik; komposisi dan ukuran unsur tata letak (judul, pengarang, ilustrasi, logo, dll.) proporsional, seimbang, dan sesuai dengan letak isi (sesuai pola); warna unsur tata letak harmonis dan memerjelas fungsi; penempatan unsur tata letak konsisten dalam satu seri; ukuran huruf judul buku lebih dominan dan proporsional; warna judul buku kontras dengan warna latar belakang; tidak terlalu banyak menggunakan kombinasi jenis huruf; tidak menggunakan huruf hias dan jenis huruf sesuai dengan huruf isi buku; ilustrasi kulit buku menggambarkan isi/materi ajar dan mengungkapkan karakter objek; dan bentuk, warna, ukuran, dan proporsi objek 
LINGUA, Vol. 12, No. 1, Maret 2015

p ISSN: 1979 9411; e ISSN: 2442 238X; Web: lingua.pusatbahasa.or.id

Pusat Kajian Bahasa dan Budaya, Surakarta, Indonesia

Suhartono, J. Parmin \& Wibowo, AN, Yermia. 2015. Pengembangan Modul Membaca dan Menulis Berbasis Uji Diagnostik untuk Meningkatkan Pemahaman Siswa SMP terhadap Materi Pokok Bahasa Indonesia. Lingua, 12(1): 23 38.

sesuai dengan realitas; c) desain isi buku (butir penilaian: penempatan unsur tata letak konsisten berdasarkan pola; pemisahan antarparagraf jelas; tidak ada widow atau orphan; bidang cetak dan marjen proporsional; marjin dua halaman yang berdampingan proporsional; spasi antara teks dengan ilustrasi sesuai; judul bab, subjudul bab, dan angka halaman lengkap; ilustrasi dan keterangan gambar (caption) lengkap; penempatan hiasan/ilustrasi sebagai latar belakang tidak mengganggu judul, teks, dan angka halaman; penempatan judul, subjudul, ilustrasi, dan keterangan gambar tidak mengganggu pemahaman; tidak menggunakan terlalu banyak jenis huruf; tidak menggunakan jenis huruf hias/dekoratif; penggunaan variasi huruf (bold, italic, all capital, dan small capital) tidak berlebihan; jenis huruf sesuai dengan materi isi; lebar susunan teks antara 45-75 karakter (sekitar 5-11 kata); spasi antarbaris susunan teks normal; spasi antarhuruf (kerning) normal; jenjang/hierarki judul-judul jelas, konsisten, dan proporsional; tidak terdapat alur putih dalam susunan teks; tanda pemotongan kata tidak mengganggu keterbacaan; ilustrasi isi mampu mengungkap makna/arti objek; bentuk ilustrasi akurat dan proporsional sesuai dengan kenyataan; keseluruhan ilustrasi serasi; goresan garis dan raster tegas dan jelas; dan ilustrasi isi kreatif dan dinamis.

Materi pokok membaca dan menulis pada jenjang SMP pada dasarnya merupakan materi-materi terpilih yang diseleksi dari KD-KD pada semester I kelas VII sampai dengan semester II kelas IX. Hasil seleksi tersebut biasanya diumumkan beberapa bulan sebelum UN dengan label Kisi-Kisi Soal UN SMP. Materi-materi pokok bidang membaca dan menulis jenjang SMP pada tahun akademik 2011/2012 sampai dengan 2013/2014 sebagai berikut. Materi pokok bidang membaca adalah 1) mengidentifikasi isi dan bagian suatu teks; 2) menentukan persamaan isi berita; 3) menentukan perbedaan penyajian berita; 4) mengidentifikasi isi teks biografi/iklan; 5) menentukan kalimat fakta/opini dalam teks iklan; 6) menyimpulkan isi paragraf; 7) mengidentifikasi isi grafik, tabel, bagan, denah; 8) mengidentifikasi unsur intrinsik puisi; 9) mengidentifikasi unsur intrinsik cerita pendek/cerita anak; 10) mengidentifikasi perbedaan karakteristik dua novel; dan 11) mengidentifikasi unsur intrinsik drama. Materi pokok bidang menulis adalah 1) menulis catatan pengalaman pada buku harian; 2) menulis pesan singkat sesuai konteks; 3) menulis laporan/pengumuman/resensi; 4) melengkapi surat pribadi/surat dinas/surat pembaca; 5) menulis rangkuman; 6) menulis teks berita sesuai konteks; 7) menulis slogan sesuai konteks; 8) menulis iklan sesuai konteks; 9) menyusun petunjuk melakukan sesuatu; 10) menulis teks pidato; 11) menulis rumusan masalah karya ilmiah/saran karya ilmiah/daftar pustaka; 12) menyunting kalimat, ejaan/tanda baca, pilihan kata; 13) melengkapi pantun; 14) melengkapi puisi; dan 15) melengkapi naskah drama.

\section{METODE}

Penelitian ini berjenis penelitian pengembangan dengan tujuan menghasilkan produk berupa modul membaca dan menulis berbasis uji diagnostik untuk meningkatkan pemahaman siswa SMP dan SMA terhadap materi-materi pokok mapel Bahasa Indonesia. Pengembangan produk bermodel siklus pengembangan instruksional Fenrich (1997). Subjek uji cobanya 
LINGUA, Vol. 12, No. 1, Maret 2015

p ISSN: 1979 9411; e ISSN: 2442 238X; Web: lingua.pusatbahasa.or.id

Pusat Kajian Bahasa dan Budaya, Surakarta, Indonesia

Suhartono, J. Parmin \& Wibowo, AN, Yermia. 2015. Pengembangan Modul Membaca dan Menulis Berbasis

Uji Diagnostik untuk Meningkatkan Pemahaman Siswa SMP terhadap Materi Pokok Bahasa Indonesia. Lingua, 12(1): 23 38.

adalah kelas IX F SMPN 28 Surabaya dengan jumlah siswa 27 orang. Data berupa isian dan catatan lapangan pada instrumen lembar kegiatan tentang proses perencanaan, perancangan, dan pengembangan modul dikumpulkan dengan teknik catat. Data berupa isian dan catatan validator pada instrumen lembar validasi kualitas isi, penyajian, kebahasaan, dan kegrafikaan modul dikumpulkan dengan teknik validasi. Data tersebut dianalisis dengan teknik alir Miles dan Huberman (1984:16-23). Data berupa skor hasil uji diagnostik dan tes akhir yang dikumpulkan dengan teknik tes kemudian dianalisis dengan teknik hitung.

\section{HASIL}

\section{Proses Perencanaan Modul}

Proses perencanaan modul terdiri atas lima kegiatan, yaitu penentuan materi uji diagnostik, pemetaan proporsi soal per materi dalam uji diagnostik, perumusan indikator soal uji diagnostik, perumusan soal uji diagnostik, dan pelaksanaan uji diagnostik dan penentuan materi modul.

\section{Penentuan Materi Uji Diagnostik}

Uji diagnostik dimaksudkan untuk mengetahui materi-materi pokok UN yang dianggap sulit oleh peserta didik. Karena itu, materi uji diagnostik disamakan dengan materimateri pokok UN tahun 2013/2014 (tahun pelaksanaan 2014) seperti yang disebutkan pada butir 2.6.

Berdasarkan uraian pada butir 2.6, materi uji diagnostik terdiri atas dua keterampilan berbahasa, yaitu membaca dan menulis. Pada keterampilan membaca terdapat 11 materi pokok dengan perincian 7 berorientasi pemahaman materi kebahasaan dan 4 berorientasi pemahaman materi kesastraan. Pada keterampilan menulis terdapat 15 materi pokok dengan perincian 12 berorientasi penerapan materi kebahasaan dan 3 berorientasi aplikasi materi kesastraan.

Kalau dipersentasekan, keterampilan membaca $42,3 \%$, sedangkan menulis $57,7 \%$. Pada keterampilan membaca, 63,6\% materinya berorientasi pemahaman materi kebahasaan, sedangkan $36,4 \%$ berorientasi pemahaman materi kesastraan. Pada keterampilan menulis, $86,7 \%$ materinya berorientasi penerapan materi kebahasaan, sedangkan $13,3 \%$ berorientasi penerapan materi kesastraan. Kalau keseluruhan materi dipersentasekan, 73,1\% merupakan materi yang berorientasi kebahasaan, sedangkan 26,9\% berorientasi kesastraan.

\section{Pemetaan Proporsi Soal Per Materi dalam Uji Diagnostik}

Pemetaan dimaksudkan untuk melihat sebaran soal UN. Dengan berdasar analisis soalsoal UN dalam dua tahun terakhir, pemetaan proporsi soal per materi dalam uji diagnostik sebagai berikut: 15 materi pokok memiliki distribusi 1 soal, 4 materi pokok 2 soal, 4 materi pokok 3 soal, 2 materi pokok 4 soal, dan 1 materi pokok 7 soal. Kalau dipersentasekan, materi pokok yang berdistribusi 1 soal sebanyak 57,69\%; 2 soal 15,38\%; 3 soal 15,38\%; 4 soal 7,69\%; dan 7 soal $4,35 \%$.

Jumlah soal pada keterampilan membaca 25 atau $50 \%$ dan menulis juga 50 buah atau $50 \%$. Pada keterampilan membaca, jumlah soal yang berorientasi pada pemahaman bahasa 13 
LINGUA, Vol. 12, No. 1, Maret 2015

p ISSN: 1979 9411; e ISSN: 2442 238X; Web: lingua.pusatbahasa.or.id Pusat Kajian Bahasa dan Budaya, Surakarta, Indonesia

Suhartono, J. Parmin \& Wibowo, AN, Yermia. 2015. Pengembangan Modul Membaca dan Menulis Berbasis Uji Diagnostik untuk Meningkatkan Pemahaman Siswa SMP terhadap Materi Pokok Bahasa Indonesia. Lingua, 12(1): 23 38.

atau 52\%; sedangkan pemahaman sastra 12 atau 48\%. Pada keterampilan menulis, jumlah soal yang berorientasi penerapan bahasa 22 atau $88 \%$; sedangkan penerapan sastra 3 atau $12 \%$.

Secara keseluruhan jumlah soal yang berorientasi kebahasaan 35 atau 70\%; sedangkan yang berorientasi kesastraan 15 atau 30\%. Hal itu menunjukkan bahwa jumlah soal yang berorientasi kebahasaan lebih dari dua kali jumlah soal yang berorientasi kesastraan.

\section{Perumusan Indikator Soal Uji Diagnostik}

Indikator soal uji diagnostik disusun dengan menggunakan dua unsur. Pertama, hal yang disajikan pada pokok soal (stem). Kedua, hal yang harus dilakukan peserta tes. Sejalan dengan KyD yang ditetapkan pemerintah, indikator soal uji diagnostik dirumuskan dengan prototipe berikut.

\begin{tabular}{|c|l|l|}
\hline Nmr. & \multicolumn{1}{|c|}{ Kemampuan yang Diujikan } & \multicolumn{1}{c|}{ Indikator Soal } \\
\hline 1 & $\begin{array}{l}\text { mengidentifikasi isi dan bagian } \\
\text { suatu teks }\end{array}$ & $\begin{array}{l}\text { Disajikan satu paragraf, peserta tes mengidentifikasi } \\
\text { gagasan utama }\end{array}$ \\
\hline
\end{tabular}

Indikator-indikator soal dapat dikelompokkan ke dalam dua kategori, yaitu indikator-indikator yang arah soalnya jelas dan indikator-indikator yang arah soalnya belum jelas. Kategori pertama bermakna bahwa kehadiran subindikator tidak diperlukan. Kebalikannya, kategori kedua bermakna bahwa kehadiran subindikator tidak diperlukan. Indikator-indikator yang arah soalnya sudah jelas tampak pada prototipe berikut.

\begin{tabular}{|c|l|l|}
\hline Nmr. & \multicolumn{1}{|c|}{ Kemampuan yang Diujikan } & \multicolumn{1}{c|}{ Indikator Soal } \\
\hline 1 & $\begin{array}{l}\text { mengidentifikasi isi dan bagian } \\
\text { suatu teks }\end{array}$ & $\begin{array}{l}\text { Disajikan satu paragraf, peserta tes mengidentifikasi } \\
\text { gagasan utama }\end{array}$ \\
\hline 2 & $\begin{array}{l}\text { Menentukan persamaan isi } \\
\text { berita }\end{array}$ & $\begin{array}{l}\text { Disajikan dua berita, peserta tes menentukan } \\
\text { persamaan isinya }\end{array}$ \\
\hline
\end{tabular}

Berbeda dengan prototipe tersebut, pada prototipe indikator berikut arah soal tidak jelas. Penyebabnya bukan rumusan indikator tidak benar, melainkan cakupan indikator luas.

\begin{tabular}{|c|l|c|}
\hline Nmr. & \multicolumn{1}{|c|}{ Kemampuan yang Diujikan } & \multicolumn{1}{c|}{ Indikator Soal } \\
\hline 1 & $\begin{array}{l}\text { mengidentifikasi unsur intrinsik } \\
\text { cerita pendek/cerita anak }\end{array}$ & Disajikan kutipan cerpen, peserta tes menentukan latar \\
\hline 2 & $\begin{array}{l}\text { mengidentifikasi unsur intrinsik } \\
\text { drama }\end{array}$ & Disajikan kutipan drama, peserta tes menentukan latar \\
\hline
\end{tabular}

Dari data dapat dijelaskan bahwa dari 50 indikator, tujuh atau $14 \%$ indikator berkategori tidak jelas. Ketidakjelasannya diuraikan sebagai berikut. 
LINGUA, Vol. 12, No. 1, Maret 2015

p ISSN: 1979 9411; e ISSN: 2442 238X; Web: lingua.pusatbahasa.or.id Pusat Kajian Bahasa dan Budaya, Surakarta, Indonesia

Suhartono, J. Parmin \& Wibowo, AN, Yermia. 2015. Pengembangan Modul Membaca dan Menulis Berbasis Uji Diagnostik untuk Meningkatkan Pemahaman Siswa SMP terhadap Materi Pokok Bahasa Indonesia. Lingua, 12(1): 23 38.

\begin{tabular}{|c|c|c|}
\hline $\begin{array}{l}\text { Kemampuan yang } \\
\text { Diujikan }\end{array}$ & Indikator Soal & Keterangan \\
\hline $\begin{array}{l}\text { mengidentifikasi } \\
\text { unsur intrinsik } \\
\text { cerita } \\
\text { pendek/cerita anak }\end{array}$ & $\begin{array}{l}\text { Disajikan kutipan } \\
\text { cerpen, peserta tes } \\
\text { menentukan latar }\end{array}$ & $\begin{array}{l}\text { Latar tidak spesifik karena tidak } \\
\text { disebutkan misalnya latar waktu } \\
\text { atau tempat. }\end{array}$ \\
\hline $\begin{array}{l}\text { mengidentifikasi } \\
\text { unsur intrinsik } \\
\text { drama }\end{array}$ & $\begin{array}{l}\text { Disajikan kutipan } \\
\text { drama, peserta tes } \\
\text { menentukan latar }\end{array}$ & $\begin{array}{l}\text { Latar tidak spesifik karena tidak } \\
\text { disebutkan misalnya latar waktu } \\
\text { atau tempat. }\end{array}$ \\
\hline $\begin{array}{l}\text { melengkapi surat } \\
\text { pribadi/surat } \\
\text { dinas/surat } \\
\text { pembaca }\end{array}$ & $\begin{array}{l}\text { Disajikan surat dinas } \\
\text { rumpang, peserta tes } \\
\text { melengkapinya }\end{array}$ & $\begin{array}{l}\text { Bagian yang rumpang tidak } \\
\text { spesifik karena tidak disebutkan } \\
\text { misalnya tujuan atau penutup. }\end{array}$ \\
\hline \multirow[t]{2}{*}{$\begin{array}{l}\text { menyunting } \\
\text { kalimat, } \\
\text { ejaan/tanda baca, } \\
\text { pilihan kata }\end{array}$} & $\begin{array}{l}\text { Disajikan kalimat yang } \\
\text { penulisan tanda bacanya } \\
\text { kurang tepat, peserta tes } \\
\text { menyuntingnya }\end{array}$ & $\begin{array}{l}\text { Tanda baca tidak spesifik karena } \\
\text { tidak disebutkan misalnya tanda } \\
\text { titik atau tanda koma. }\end{array}$ \\
\hline & $\begin{array}{l}\text { Disajikan kalimat yang } \\
\text { penulisan huruf } \\
\text { kapitalnya kurang tepat, } \\
\text { peserta tes } \\
\text { menyuntingnya }\end{array}$ & $\begin{array}{l}\text { Huruf kapital tidak spesifik } \\
\text { karena tidak disebutkan misalnya } \\
\text { huruf kapital pada judul atau } \\
\text { nama diri. }\end{array}$ \\
\hline melengkapi pantun & $\begin{array}{l}\text { Disajikan pantun } \\
\text { rumpang, peserta tes } \\
\text { melengkapinya. }\end{array}$ & $\begin{array}{l}\text { Bagian yang rumpang tidak } \\
\text { spesifik karena tidak disebutkan } \\
\text { misalnya bagian sampiran atau } \\
\text { bagian isi. }\end{array}$ \\
\hline $\begin{array}{l}\text { melengkapi naskah } \\
\text { drama }\end{array}$ & $\begin{array}{l}\text { Disajikan naskah drama } \\
\text { rumpang, peserta tes } \\
\text { melengkapinya. }\end{array}$ & $\begin{array}{l}\text { Bagian yang rumpang tidak } \\
\text { spesifik karena tidak disebutkan } \\
\text { misalnya bagian dialog atau } \\
\text { bagian lakuan) }\end{array}$ \\
\hline
\end{tabular}

\section{Perumusan Soal Uji Diagnostik}

Dengan berdasar hasil pemetaan proporsi soal, disusun soal uji diagnostik sesuai dengan beberapa ketentuan penulisan soal UN. Pertama, jumlah soal lima puluh buah. Kedua, terdapat satu jawaban benar dan tiga butir pengecoh per soal. Untuk kepentingan standardisasi soal, soal-soal dalam uji diagnostik tersebut diperoleh melalui adaptasi soal dari beberapa tipe soal UN yang diselenggarakan pada tahun 2011/2012 (tahun pelaksanaan 2013). Sebaran soal dan kunci jawaban pada uji diagnostic tampak pada prototipe berikut.

\begin{tabular}{|l|l|l|ll|l|}
\hline $\begin{array}{c}\text { Nmr. } \\
\text { Soal }\end{array}$ & $\begin{array}{c}\text { Keterampilan } \\
\text { Berbahasa }\end{array}$ & $\begin{array}{c}\text { Aspek/ } \\
\text { Bidang }\end{array}$ & \multicolumn{1}{|c|}{ (Sub)materi } & $\begin{array}{c}\text { Kunci } \\
\text { Jawaban }\end{array}$ \\
\hline 1 & Membaca & Bahasa & $\begin{array}{l}\text { Mengidentifikasi simpulan } \\
\text { paragraf }\end{array}$ & C \\
\hline 2 & Membaca & Bahasa & $\begin{array}{l}\text { Mengidentifikasi } \\
\text { utama paragraf }\end{array}$ & gagasan & B \\
\hline
\end{tabular}


LINGUA, Vol. 12, No. 1, Maret 2015

p ISSN: 1979 9411; e ISSN: 2442 238X; Web: lingua.pusatbahasa.or.id Pusat Kajian Bahasa dan Budaya, Surakarta, Indonesia

Suhartono, J. Parmin \& Wibowo, AN, Yermia. 2015. Pengembangan Modul Membaca dan Menulis Berbasis

Uji Diagnostik untuk Meningkatkan Pemahaman Siswa SMP terhadap Materi Pokok Bahasa Indonesia. Lingua, 12(1): 23 38.

\section{Pelaksanaan Uji Diagnostik dan Penentuan Materi modul}

Uji diagnostik dilaksanakan pada Kamis 27 Maret 2014 dengan jumlah siswa 31 orang. Di antara 31 siswa, 4 siswa tidak menjadi subjek uji coba karena tidak mengikuti tes capaian. Hasil uji diagnostik dengan gradasi tingkat kesulitan tinggi ke rendah sebagai berikut.

\begin{tabular}{|c|c|c|c|}
\hline $\begin{array}{l}\text { Nmr. } \\
\text { Soal }\end{array}$ & (Sub)materi & $\begin{array}{c}\text { Jml. } \\
\text { Penjawab } \\
\text { Benar }\end{array}$ & $\begin{array}{c}\text { Persentase } \\
\text { Penjawab } \\
\text { Benar }\end{array}$ \\
\hline 1 & Melengkapi surat resmi & 1 & 4 \\
\hline 2 & $\begin{array}{l}\text { Mengidentifikasi isi teks biografi (hal yang dapat } \\
\text { diteladani) }\end{array}$ & 2 & 7 \\
\hline 3 & Mengidentifikasi tempat/lokasi dalam denah & 4 & 15 \\
\hline 4 & Mengidentifikasi arah perjalanan dalam denah & 8 & 30 \\
\hline 5 & Mengidentifikasi watak tokoh cerpen & 8 & 30 \\
\hline 6 & Menulis rangkuman & 9 & 33 \\
\hline 7 & Mengidentifikasi perbedaan amanat puisi & 9 & 33 \\
\hline 8 & $\begin{array}{l}\text { Mengidentifikasi cara pengarang menggambarkan watak } \\
\text { tokoh cerpen }\end{array}$ & 12 & 44 \\
\hline 9 & Mengidentifikasi isi kalimat pada iklan & 13 & 48 \\
\hline 10 & Mengidentifikasi perbedaan karakteristik dua novel & 13 & 48 \\
\hline 11 & Menentukan perbedaan penyajian berita & 14 & 52 \\
\hline 12 & Melengkapi puisi & 14 & 52 \\
\hline 13 & Mengidentifikasi larik bermajas pada puisi & 15 & 56 \\
\hline 14 & Menyunting kalimat & 16 & 59 \\
\hline 15 & Mengidentifikasi maksud teks iklan & 18 & 67 \\
\hline 16 & Mengidentifikasi simpulan paragraph & 19 & 70 \\
\hline 17 & Mengidentifikasi konflik dalam cerita & 19 & 70 \\
\hline 18 & Menyunting ejaan (tanda baca) & 19 & 70 \\
\hline 19 & Mengidentifikasi amanat cerita cerita & 20 & 74 \\
\hline 20 & Menentukan persamaan isi berita & 22 & 81 \\
\hline 21 & Mengidentifikasi isi teks biografi (keistimewaan tokoh) & 22 & 81 \\
\hline 22 & Mengidentifikasi adat dalam cerita & 22 & 81 \\
\hline 23 & Menulis saran penelitian & 22 & 81 \\
\hline 24 & Mengidentifikasi kalimat fakta pada iklan & 23 & 85 \\
\hline 25 & Melengkapi surat pribadi & 23 & 85 \\
\hline 26 & Menulis rumusan masalah penelitian & 23 & 85 \\
\hline 27 & Mengidentifikasi latar cerpen & 24 & 89 \\
\hline 28 & Menyunting ejaan (huruf kapital) & 24 & 89 \\
\hline 29 & Menulis slogan & 24 & 89 \\
\hline 30 & Menulis teks berita & 25 & 93 \\
\hline 31 & Menulis iklan & 25 & 93 \\
\hline 32 & Menulis petunjuk & 25 & 93 \\
\hline 33 & Menulis pidato & 25 & 93 \\
\hline
\end{tabular}


LINGUA, Vol. 12, No. 1, Maret 2015

p ISSN: 1979 9411; e ISSN: 2442 238X; Web: lingua.pusatbahasa.or.id Pusat Kajian Bahasa dan Budaya, Surakarta, Indonesia

Suhartono, J. Parmin \& Wibowo, AN, Yermia. 2015. Pengembangan Modul Membaca dan Menulis Berbasis

Uji Diagnostik untuk Meningkatkan Pemahaman Siswa SMP terhadap Materi Pokok Bahasa Indonesia. Lingua, 12(1): 23 38.

\begin{tabular}{|l|l|l|l|}
\hline 34 & Menulis pidato (perbaikan sapaan) & 25 & 93 \\
\hline 35 & Menulis daftar pustaka & 25 & 93 \\
\hline 36 & Mengidentifikasi simpulan isi tabel & 26 & 96 \\
\hline 37 & Mengidentifikasi tema puisi & 26 & 96 \\
\hline 38 & Mengidentikasi latar drama & 26 & 96 \\
\hline 39 & Menulis laporan & 26 & 96 \\
\hline 40 & Menulis resensi & 26 & 96 \\
\hline 41 & Melengkapi kalimat petunjuk & 26 & 96 \\
\hline 42 & Melengkapi pantun & 26 & 96 \\
\hline 43 & Mengidentifikasi gagasan utama paragraf & 27 & 100 \\
\hline 44 & Mengidentifikasi isi grafik & 27 & 100 \\
\hline 45 & Mengidentifikasi suasana dalam naskah drama & 27 & 100 \\
\hline 46 & Menulis buku harian & 27 & 100 \\
\hline 47 & Menulis pesan singkat & 27 & 100 \\
\hline 48 & Menulis pengumuman & 27 & 100 \\
\hline 49 & Melengkapi surat pembaca & 27 & 100 \\
\hline 50 & Melengkapi naskah drama & 27 & 100 \\
\hline
\end{tabular}

Berdasar hasil uji diagnostik tersebut, materi pokok dikelompokkan ke dalam dua kategori. Materi pokok yang dijawab benar oleh $285 \%$ peserta didik dikategorikan materi mudah, sedangkan yang $<85 \%$ dikategorikan materi sulit. Dalam hal ini digunakan kriteria rendah, yaitu $85 \%$, karena kompetensi akademik subjek penelitian berkategori tengah atau sedang. Dengan menggunakan indikator tersebut, materi pokok berkategori sulit yang dijadikan dasar penyusunan modul adalah sebagai berikut.

\begin{tabular}{|l|l|l|l|l|}
\hline Nmr. & $\begin{array}{l}\text { Nmr. } \\
\text { Soal }\end{array}$ & \multicolumn{1}{|c|}{ (Sub)materi } & $\begin{array}{c}\text { Jml. } \\
\text { Penjawab } \\
\text { Benar }\end{array}$ & $\begin{array}{c}\text { Persentase } \\
\text { Penjawab } \\
\text { Benar }\end{array}$ \\
\hline 1 & 1 & Mengidentifikasi simpulan paragraf & 19 & 70 \\
\hline 2 & 3 & Menentukan persamaan isi berita & 22 & 81 \\
\hline 3 & 4 & Menentukan perbedaan penyajian berita & 14 & 52 \\
\hline 4 & 5 & $\begin{array}{l}\text { Mengidentifikasi isi teks biografi (keistimewaan } \\
\text { tokoh) }\end{array}$ & 22 & 81 \\
\hline 5 & 6 & $\begin{array}{l}\text { Mengidentifikasi isi teks biografi (hal yang dapat } \\
\text { diteladani) }\end{array}$ & 2 & 7 \\
\hline 6 & 7 & Mengidentifikasi isi kalimat pada iklan & 13 & 48 \\
\hline 7 & 8 & Mengidentifikasi maksud teks iklan & 18 & 67 \\
\hline 8 & 12 & Mengidentifikasi arah perjalanan dalam denah & 8 & 30 \\
\hline 9 & 13 & Mengidentifikasi tempat/lokasi dalam denah & 4 & 15 \\
\hline 10 & 15 & Mengidentifikasi larik bermajas pada puisi & 15 & 56 \\
\hline 11 & 16 & Mengidentifikasi perbedaan amanat puisi & 9 & 33 \\
\hline 12 & 18 & Mengidentifikasi watak tokoh cerpen & 8 & 30 \\
\hline 13 & 19 & $\begin{array}{l}\text { Mengidentifikasi cara } \\
\text { menggambarkan watak tokoh cerpen }\end{array}$ & 44 \\
\hline
\end{tabular}


LINGUA, Vol. 12, No. 1, Maret 2015

p ISSN: 1979 9411; e ISSN: 2442 238X; Web: lingua.pusatbahasa.or.id Pusat Kajian Bahasa dan Budaya, Surakarta, Indonesia

Suhartono, J. Parmin \& Wibowo, AN, Yermia. 2015. Pengembangan Modul Membaca dan Menulis Berbasis

Uji Diagnostik untuk Meningkatkan Pemahaman Siswa SMP terhadap Materi Pokok Bahasa Indonesia. Lingua, 12(1): 23 38.

\begin{tabular}{|l|l|l|l|l|}
\hline 14 & 20 & Mengidentifikasi amanat cerita anak & 20 & 74 \\
\hline 15 & 21 & Mengidentifikasi konflik dalam novel & 19 & 70 \\
\hline 16 & 22 & Mengidentifikasi adat dalam novel & 22 & 81 \\
\hline 17 & 23 & $\begin{array}{l}\text { Mengidentifikasi perbedaan karakteristik dua } \\
\text { novel }\end{array}$ & 13 & 48 \\
\hline 18 & 32 & Melengkapi surat resmi & 1 & 4 \\
\hline 19 & 34 & Menulis rangkuman & 9 & 33 \\
\hline 20 & 43 & Menulis saran penelitian & 22 & 81 \\
\hline 21 & 45 & Menyunting kalimat & 16 & 59 \\
\hline 22 & 46 & Menyunting ejaan (tanda baca) & 19 & 70 \\
\hline 23 & 49 & Melengkapi puisi & 14 & 52 \\
\hline
\end{tabular}

\section{Proses Perancangan Modul}

Modul membaca dan menulis yang berisi pengembangan materi-materi pokok UN dirancang dengan prototipe fitur berikut.

\begin{tabular}{|c|c|c|c|c|}
\hline $\begin{array}{l}\text { Nmr. } \\
\text { Soal }\end{array}$ & $\begin{array}{c}\text { Keterampilan } \\
\text { Berbahasa } \\
\end{array}$ & $\begin{array}{l}\text { Aspek/B } \\
\text { idang }\end{array}$ & (Sub)materi & Isi Modul \\
\hline \multirow[t]{6}{*}{1} & \multirow[t]{6}{*}{ Membaca } & \multirow[t]{6}{*}{ Bahasa } & \multirow{6}{*}{$\begin{array}{l}\text { Mengidentifikasi } \\
\text { simpulan paragraf }\end{array}$} & Konsep \\
\hline & & & & Contoh-contoh soal \\
\hline & & & & Kunci \\
\hline & & & & Pembahasan \\
\hline & & & & Perlatihan \\
\hline & & & & Tindak lanjut \\
\hline
\end{tabular}

\section{Proses Pengembangan Modul}

Proses pengembangan modul didasarkan pada materi pokok berkategori sulit dan fitur yang ditetapkan. Dalam proses pengembangan tersebut, dilakukan penyusunan materi awal, revisi, dan finalisasi berdasarkan reviu internal dan validasi. Hasil validasi modul oleh praktisi dan pakar terkait sebagai berikut.

\begin{tabular}{|c|c|c|}
\hline \multirow[t]{2}{*}{ Aspek/Subaspek } & \multicolumn{2}{|c|}{$\begin{array}{l}\text { Nilai } \\
\text { Validator }\end{array}$} \\
\hline & 1 & 2 \\
\hline \multicolumn{3}{|l|}{ 1. Kelayakan isi } \\
\hline $\begin{array}{l}\text { Kesesuaian uraian materi dengan kemampuan yang diujikan (KyD) } \\
\text { (kelengkapan dan kedalaman materi) }\end{array}$ & 4 & 4 \\
\hline Keakuratan materi (keakuratan konsep dan contoh) & 4 & 4 \\
\hline \multicolumn{3}{|l|}{ 2. Kelayakan penyajian } \\
\hline $\begin{array}{l}\text { Teknik penyajian (konsistensi sistematika penyajian, keruntutan } \\
\text { konsep, dan keseimbangan antar-KyD) }\end{array}$ & 3 & 3 \\
\hline Penyajian materi (merangsang metakognisi dan kreasi berpikir siswa) & 4 & 3 \\
\hline Kelengkapan penyajian (bagian pendahulun, isi, dan penyudah) & 3 & 3 \\
\hline 3. Kelayakan kebahasaan & & \\
\hline
\end{tabular}


LINGUA, Vol. 12, No. 1, Maret 2015

p ISSN: 1979 9411; e ISSN: 2442 238X; Web: lingua.pusatbahasa.or.id Pusat Kajian Bahasa dan Budaya, Surakarta, Indonesia

Suhartono, J. Parmin \& Wibowo, AN, Yermia. 2015. Pengembangan Modul Membaca dan Menulis Berbasis Uji Diagnostik untuk Meningkatkan Pemahaman Siswa SMP terhadap Materi Pokok Bahasa Indonesia. Lingua, 12(1): 23 38.

\begin{tabular}{|c|c|c|}
\hline $\begin{array}{l}\text { Kesesuaian dengan tingkat perkembangan peserta didik (intelektual dan } \\
\text { sosio-emosional) }\end{array}$ & 4 & 4 \\
\hline Kekomunikatifan (tingkat keterbacaan dan ketepatan bahasa) & 3 & 4 \\
\hline $\begin{array}{l}\text { Keruntutan dan kesatuan gagasan (antar-KyD, antarparagraf, dan } \\
\text { antarkalimat) }\end{array}$ & 4 & 4 \\
\hline \multicolumn{3}{|l|}{ 4. Kelayakan kegrafikaan } \\
\hline Ukuran modul (menggunakan A4 dan sesuai dengan tipe materi) & 4 & 4 \\
\hline Desain kulit modul (penampilan tata letak harmonis) & 3 & 3 \\
\hline Tipografi kulit modul (huruf sederhana, menarik, dan mudah dibaca) & 3 & 3 \\
\hline Ilustrasi kulit buku (mencerminkan isi) & 3 & 3 \\
\hline $\begin{array}{l}\text { Desain isi buku (tata letak konsisten, harmonis, lengkap, dan } \\
\text { memercepat pemahaman) }\end{array}$ & 3 & 3 \\
\hline $\begin{array}{l}\text { Tipografi isi buku (tipografi sederhana, mudah dibaca, dan } \\
\text { memudahkan pemahaman) }\end{array}$ & 3 & 4 \\
\hline $\begin{array}{l}\text { Ilustrasi isi (memerjelas dan memermudah pemahaman serta } \\
\text { menimbulkan daya tarik) }\end{array}$ & 3 & 3 \\
\hline Rerata & 3,4 & 3,47 \\
\hline Rerata akhir & \multicolumn{2}{|c|}{3,44} \\
\hline
\end{tabular}

Berdasarkan skor hasil validasi tersebut, dapat dinyatakan bahwa secara umum modul membaca dan menulis yang dikembangkan berkategori baik. Kategori tersebut mengisyaratkan bahwa modul memenuhi kelayakan untuk digunakan dalam pembelajaran.

Di samping memberikan nilai, validator juga memberikan masukan. Masukan tersebut di antaranya materi perlu ditajamkan, jumlah contoh soal perlu diperbanyak, dan jawaban benar atau jawaban salah perlu dipastikan. Dalam hal penajaman materi diperlukan pendalaman penjelasan dengan memanfaatkan referensi-referensi yang praktis dan mudah dipahami siswa. Dalam hal contoh soal, jumlah soal per materi pokok disarankan minimal sepuluh buah dengan kualitas dan jenis soal yang variatif. Dalam hal pemastian jawaban benar atau salah, perlu ada penjelasan yang rasional, memadai, dan mudah dipahami tentang mengapa misalnya pilihan jawaban A yang benar. Kalau B, C, dan D benar, apa alasannya.

\section{Pemahaman Siswa terhadap Materi Sebelum Menggunakan Modul}

Berdasarkan data hasil uji diagnostik diketahui bahwa soal yang berkategori sulit berjumlah 23 buah, yaitu soal nomor 1, 3, 4, 5, 6, 7, 8, 12, 13, 15, 16, 18, 19, 20, 21, 22, 23, 32, 34, 43, 45, 46, dan 49. Penjawab benar soal nomor 1sebanyak 19 siswa, nomor 322 siswa, nomor 414 siswa, nomor 522 siswa, nomor 62 siswa, nmr 713 siswa, nomor 818 siswa, 128 siswa, nomor 134 siswa, nomor 1515 siswa, nomor 169 siswa, nomor 188 siswa, nomor 1912 siswa, nomor 2020 siswa, nomor 2119 siswa, nomor 2222 siswa, nomor 2313 siswa, nomor 321 siswa, nomor 349 siswa, nomor 4322 siswa, nomor 4516 siswa, nomor 4619 siswa, dan nomor 4914 siswa.

Di antara soal-soal berkategori sulit tersebut, soal nomor 32 merupakan soal tersulit karena dijawab benar oleh satu siswa saja. Berikut soal tersulit tersebut. 
Bacalah kutipan surat resmi berikut!

\begin{tabular}{|c|c|}
\hline & $\begin{array}{c}\text { ORGANISASI SISWA INTRA SEKOLAH } \\
\text { SMP PENERBANGAN } \\
\text { Jalan Adi Sucipto, } 12 \text { Tlp. (0274) } 531848 \text { Yogyakarta }\end{array}$ \\
\hline Nomor : & 009/OSIS/SMP/2014 \\
\hline Perihal : & Undangan \\
\hline \multicolumn{2}{|c|}{ Dengan hormat, } \\
\hline \multicolumn{2}{|c|}{$\begin{array}{l}\text { Dengan ini kami mengundang Bapak untuk membuka kegiatan kemah bersama SMP Penerbangan } \\
\text { yang akan dilaksanakan pada: }\end{array}$} \\
\hline \multicolumn{2}{|r|}{ Senin, 30 Mei 2014} \\
\hline pukul & $13.00 \mathrm{WIB}$ \\
\hline tempat & Halaman SMP Penerbangan \\
\hline
\end{tabular}

Bagian yang tepat untuk melengkapi surat undangan tersebut adalah ...

A. Yth. Bapak dan Ibu Guru SMP Penerbangan Di Yogyakarta

B. Kepada

Yth. Kepala TU SMP Penerbangan Yogyakarta di Yogyakarta

C. Yth. Kepala SMP Penerbangan Yogyakarta di Yogyakarta

D. Yth. Bapak Kepala SMP Penerbangan Yogyakarta di Yogyakarta

Telah diuraikan di depan bahwa pada 23 soal yang berkategori sulit, sebaran jumlah penjawab benar tidak sama. Ada soal yang jumlah penjawab benarnya 22 siswa dan ada soal yang jumlah penjawab benarnya hanya 1 siswa. Kalau direratakan, jumlah penjawab benar per soal adalah $321 / 621=51,69 \%$ dari 27 subjek.

\section{Pemahaman Siswa terhadap Materi Sesudah Menggunakan Modul}

Pemahaman siswa terhadap materi pokok sesudah menggunakan modul sebagai berikut. dasarkan data hasil tes capaian diketahui bahwa soal yang berkategori sulit berjumlah 23 buah, yaitu soal nomor 1, 3, 4, 5, 6, 7, 8, 12, 13, 15, 16, 18, 19, 20, 21, 22, 23, 32, 34, 43, 45, 46, dan 49. Penjawab benar soal nomor 1 sebanyak 26 siswa, nomor 327 siswa, nomor 4 26 siswa, nomor 518 siswa, nomor 621 siswa, nomor 7 tanpa penjawab benar, nomor 86 siswa, nomor 1223 siswa, nomor 1327 siswa, nomor 1523 siswa, nomor 1621 siswa, nomor 1825 siswa, nomor 1910 siswa, nomor 2019 siswa, nomor 2121 siswa, nomor 2220 siswa, nomor 2321 siswa, nomor 3216 siswa, nomor 3425 siswa, nomor 4324 siswa, nomor 4523 siswa, nomor 4617 siswa, dan nomor 4926 siswa. 
LINGUA, Vol. 12, No. 1, Maret 2015

p ISSN: 1979 9411; e ISSN: 2442 238X; Web: lingua.pusatbahasa.or.id Pusat Kajian Bahasa dan Budaya, Surakarta, Indonesia

Suhartono, J. Parmin \& Wibowo, AN, Yermia. 2015. Pengembangan Modul Membaca dan Menulis Berbasis Uji Diagnostik untuk Meningkatkan Pemahaman Siswa SMP terhadap Materi Pokok Bahasa Indonesia. Lingua, 12(1): 23 38.

Di antara soal-soal tersebut, soal nomor 7 merupakan soal berkategori aneh karena tidak seorang pun yang dapat menjawab dengan benar, sementara pada uji diagnostik soal tersebut dijawab benar oleh 13 siswa. Berikut soal berkategori aneh tersebut.

Perhatikan kutipan berikut untuk menjawab soal nomor 5 dan 6 !

Ki Hajar Dewantara lahir di Yogyakarta, 2 Mei 1889. Terlahir dengan nama

Raden Mas Soewardi Soeryaningrat. Ia berasal dari lingkungan keluarga Keraton Yogyakarta. Saat berusia 40 tahun, ia berganti nama menjadi Ki Hadjar Dewantara. Sejak saat itu, ia tidak lagi menggunakan gelar kebangsawanan di depan namanya. Hal ini dimaksudkan supaya ia dapat bebas dekat dengan rakyat. Ulet sebagai seorang wartawan muda, juga aktif dalam berorganisasi sosial dan politik. Pada tahun 1908, ia aktif pada seksi propaganda Boedi Oetomo untuk menyosialisasikan dan menggugah kesadaran masyarakat Indonesia mengenai pentingnya persatuan dan kesatuan dalam berbangsa dan bernegara.

7. Hal yang patut diteladani pada tokoh tersebut adalah ....

A. berganti nama supaya dapat dekat dengan rakyat

B. ulet sebagai seorang wartawan dan aktif dalam berorganisasi

C. bangga mendapat sahabat seperti Boedi Oetomo

D. dilahirkan di kalangan keluarga keraton

Seperti halnya pada uji diagnostik, sebaran jumlah penjawab benar pada 23 soal berkategori sulit dalam tes capaian juga tidak sama. Terdapat soal yang jumlah penjawab benarnya 27 siswa dan terdapat soal yang tanpa penjawab benar. Kalau direratakan, jumlah penjawab benar per soal adalah 464/621=74,72\% dari 27 subjek. Kalau dibandingkan dengan rerata penjawab benar dalam uji diagnostik, rerata penjawab benar pada tes capaian meningkat $23,03 \%$.

\section{SIMPULAN}

1) Pengembangan modul membaca dan menulis untuk SMP dilakukan melalui tahap perencanaan, perancangan, dan pengembangan modul. Pada tahap perencanaan dilakukan berbagai kegiatan hingga diperoleh 23 materi pokok berkategori sulit yang kemudian dikembangkan menjadi modul. Pada tahap perancangan dilakukan penentuan fitur modul yang terdiri atas tiga komponen, yaitu keterampilan berbahasa, kemampuan yang diujikan, dan isi modul (konsep, contoh-contoh soal, kunci jawaban, pembahasan, perlatihan, dan tindak lanjut). Pada tahap pengembangan dilakukan penyusunan materi, pereviuan, dan pemvalidasian.

2) Rerata pemahaman peserta didik terhadap materi pokok sebelum menggunakan modul adalah 51,69\%. Rerata pemahaman peserta didik terhadap materi pokok sesudah menggunakan modul adalah $74,72 \%$. Dengan demikian, rerata penjawab benar meningkat $23,03 \%$. 
LINGUA, Vol. 12, No. 1, Maret 2015

p ISSN: 1979 9411; e ISSN: 2442 238X; Web: lingua.pusatbahasa.or.id Pusat Kajian Bahasa dan Budaya, Surakarta, Indonesia

Suhartono, J. Parmin \& Wibowo, AN, Yermia. 2015. Pengembangan Modul Membaca dan Menulis Berbasis Uji Diagnostik untuk Meningkatkan Pemahaman Siswa SMP terhadap Materi Pokok Bahasa Indonesia.

Lingua, 12(1): 23 38.

\section{DAFTAR RUJUKAN}

Depdiknas. 2005. Pedoman Penulisan Buku Pelajaran. Jakarta: Depdiknas.

Dick, Walter dan Carey, Lou. 1990. The Systematic Design of Instruction. Harper Collins.

Dubin, Fraida dan Olshtain, Elite. 1986. Course Design: Developing Program $s$ and Materials for Language Learning. Cambridge: Cambridge University Press.

Fenrich, Peter. 1997. Practical Guidelines for Creating Instructional Multimedia Application. Fort Wort: The Dryden Press.

Miles, M. B. \& Huberman, A. M.. 1984. Qualitative Data Analysis A Sourcebook of New Methods. London: Sage Publications.

Pusat Perbukuan. 2005. Pedoman Pengembangan Buku Pelajaran. Jakarta: Pusat Perbukuan.

Richard, Jack C. 2003. Curricullum Development in Language Teaching. Cambridge: Cambridge University Press. 